\title{
THE IMPACT OF EUROPEANISATION ON NATURE PROTECTION SYSTEM OF CROATIA: EXAMPLE OF THE ESTABLISHMENT OF MULTI-LEVEL GOVERNANCE SYSTEM OF PROTECTED AREAS NATURA 2000
}

\author{
Aleksandar Šobot and Andrej Lukšič
}

\author{
Center for Political Theory \\ University of Ljubljana \\ Kardeljeva ploščad 5, 1000 Ljubljana, Slovenia \\ e-mail: ecosobot@gmail.com
}

Abstract

The Europeanisation of South Eastern Europe led to the pre-accession and accession process of joining Croatia to the European Union. Croatia's accession to the formal process of accession to the European Union started in 2003. This process lasted until 2012. Then, in 2013, Croatia joined the European Union. This paper examines the impact of Europeanization during this period on the nature protection system in the case of Croatia while establishing multi-level governance system of protected areas NATURA 2000.

The analysis of the establishment of multi-level governance system is performed according the morphogenetic model in three cycles as case study. Case study is organized with the help of interviews and desk analysis of the relevant documents. In the first cycle were explained the projects of implementation of NATURA 2000 in Croatia and its changing impacts on national legislation in the area of nature protection. The second cycle explains the role of the main actors in the establishment of multi-level governance system of NATURA 2000. The third cycle outlines the contributes to the establishment of multi-level governance system of NATURA 2000 in nature protection system of Croatia and future challenges of the nature protection system of Croatia. The main conclusions emphasize that the major changes due to implementation of European ecological network NATURA 2000 into the national system of Croatian nature protection, which led to transformation of governmental institutions and equal inclusion of non-governmental organizations into the system of decision making.

Keywords: Europeanisation, South Eastern Europe, Croatia, accession to the European Union, nature protection system, Natura 2000

\section{INTRODUCTION}

\subsection{Nature protection in the European Union}

Biodiversity loss is considered to be the leading problem in the $21^{\text {st }}$ century and nature protection has become a political issue at the global level. The European Union (EU) has a leading role in nature protection on an international level as there are 28 countries involved in the common system of nature protection. 
The system of nature protection at the EU level is based on the international obligations of sustainable development (Giljum et al., 2005; Ferranti et al., 2010; Winter et al., 2014; Winkel et al., 2015). The concept of sustainable development ${ }^{1}$ (SD), based on the 1987 Brundtland Report (BR) and the Earth Summit in Rio de Janeiro in 1992, emerged in order to protect nature on a global level, which is the main pillar of economic and social development (Lukšič, 2010). The implementation of the objectives of nature protection is carried out through the democratic principles that are a prerequisite for SD (Stringer and Paavola, 2013; Niedziałkowski et al., 2015).

The objectives of nature protection at the EU level arising from the concept of SD at the international level are the Birds Directive (BD) and the Habitats Directive (HD) ${ }^{2}$ (Rosa and Da Silva, 2005; Wurzel, 2008; Ferranti et al., 2010; Louette et al., 2011; Winter et al., 2014; Winkel et al., 2015). The democratic principles for achieving these goals according to the concept of SD allow for access to information and the opportunity for non-governmental actors to participate in decision-making. These principles are an integral part of the Aarhus Convention ${ }^{3}$ (AC). In this way, the $\mathrm{AC}$ has become an essential part of achieving the objectives of the $\mathrm{BD}$ and $\mathrm{HD}$ at the EU level according to the concept of SD (Stringer and Paavola, 2013; Niedziałkowski et al., 2015).

\subsection{Europeanization of South Eastern Europe}

Extending the EU has led to the process of Europeanization ${ }^{4}$ of South Eastern Europe (SEE), which in turn has led to altering the nature protection system in these countries (Cent et al., 2014) according to the concept of SD. Europeanization leads to the integration of EU nature protection policy into the national policy on nature protection (Gioti Papadaki, 2012; Kay, 2014). EU nature protection policy is based on the goals and principles of international commitments and in the process of Europeanization these commitments are implemented into national legislation as a political condition for EU accession (Baker, 2003; Denti, 2014). One such political condition is the implementation of the objectives of the $\mathrm{BD}$ and HD into national legislation (Fernández et al., 2010; Kapaciauskaite, 2011; Krenova and Kindlmann, 2015). These directives are the two basic pillars of Natura 20005 (N2000) (Rosa and Da Silva, 2005; Wurzel,

\footnotetext{
1 Sustainable development implies social and economic progress which does not jeopardize natural systems (Lukšič, 2010).

2 Council Directive (79/409/EEC) of 2 April 1979 on the conservation of wild birds has the aim and role of protection of migratory bird species and their habitats (EEC, 1979); Council Directive (92/43/EEC) of 21 May 1992 on the conservation of natural habitats and of wild fauna and flora has the aim and role of protecting biodiversity (EEC, 1992).

3 The Aarhus Convention (AC) includes the Directives on public access to environmental information, public participation in decision-making and the EC Regulation on access to justice in environmental matters. 4 The notion of Europeanization can have several meanings by which the basic meanings of this notion are EU influence on national legislation (policy), system (polity) and politics.

5 Natura 2000 represents the European Ecological Network of Protected Areas; Natura 2000 is the basis of nature protection at the EU level in line with the concept of SD (Ferranti et al., 2010; Winkel et al., 2015).
} 
2008; Louette et al., 2011; Pietrzyk-Kaszyńska et al., 2012; Winter et al., 2014; Winkel et al., 2015).

The implementation of N2000 represents the political commitment necessary for EU accession (Baker, 2003; Kati et al., 2014) and requires the establishment of multi-level governance (MLG) of N2000 (Cent et al., 2014; Niedziałkowski et al., 2015). Thus the establishment of MLG of N2000 requires the implementation of the objectives of the $\mathrm{BD}$ and $\mathrm{HD}$ into national legislation. The $\mathrm{BD}$ and $\mathrm{HD}$ indirectly require the implementation of the AC (Ferranti et al., 2010; Stringer and Paavola, 2013; Cent et al., 2014; Winter et al., 2014), which is the basic pillar of MLG on nature protection at the EU level, in line with the concept of SD (Niedziałkowski et al., 2015).

\subsection{Establishment of MLG of N2000}

The implementation of the objectives of the $\mathrm{BD}, \mathrm{HD}$ and $\mathrm{AC}$ into national legislation leads to changes in national legislation. These changes are based on the changing relationship in decision-making at the national level with the inclusion of new actors in the national system of nature protection and causes changes to the roles of the old actors (Beunen and de Vries, 2011). Niedziałkowski et al. (2015) reported that the national legislation of nature protection is the starting point for work on the establishment of MLG of N2000. National legislation defines the main actors and their role in nature protection (and conservation) in establishing MLG of N2000. Lockwood et al. (2010) suggest that the roles of the main actors in the establishment of MLG are defined according to international principles implemented into national legislation. Lukšič (2002); and Stringer and Paavola (2013) reported that the newly created role of major actors in nature protection are defined according to the principles of the $\mathrm{AC}$, which are a prerequisite to achieve the objectives of nature protection (BD and $\mathrm{HD}$ ) in accordance with the concept of SD.

Thus MLG of N2000 on the principles of the AC leads to a sharing of responsibility between governmental and non-governmental actors in MLG of nature protection at the national level (Niedziałkowski et al., 2015). Cent et al. (2014) state that the establishment of MLG of N2000 leads to sharing power between higher levels of governance (governmental institutions) and lower levels of governance (non-governmental organizations) and the involvement of all actors in decision-making. Mertens (2013) states that in addition to governmental and non-governmental actors, the EU also has an important role.

\subsection{Roles of the main actors in the establishment of MLG of N2000}

The role of the EU in the process of establishing MLG of N2000 is to fund and coordinate the implementation of the objectives and principles of nature protection in national legislation (Stubbs, 2005; Wurzel, 2008; EEA, 2010; Ferranti et al., 2010; Mertens, 2013; Kati et al., 2014); to ensure the transfer of knowledge from the EU level (Jordan et al., 2000; Giljum et al., 2005; Brulle, 2010); to ensure transparency and equal involvement of governmental and non-governmental actors in decision-making 
(Kohler-Koch and Rittberger, 2006; Beunen and de Vries, 2011); and to preserve international goals in the national legislation (Jordan, 1998).

Governmental actors have a legitimate responsibility for the implementation of international agreements (Lockwood et al. 2009). Cent et al. (2014) reported that governmental actors are responsible for the process of organizing and establishing MLG of N2000, the establishment of which includes a number of governmental institutions (actors) to communicate, interact and make joint decisions. According to the national legislation, the main governmental actors are determined in the process of establishing MLG of N2000. Their roles are mostly defined by the principles of the AC (Lukšič, 1999, 2001 ${ }^{6}, 2002$; Stringer and Paavola, 2013) in the collection of information and involvement of non-governmental actors in decision-making in line with the concept of SD (Wurzel, 2008).

Non-governmental actors, such as non-governmental organizations (NGOs) in the field of nature protection, have been given the opportunity for equal participation in decision-making along with governmental actors in the process of establishing MLG of N2000 (Weber and Christophersen, 2002; Ferranti et al., 2010; Cent et al., 2013; Stringer and Paavola, 2013). Newig and Fritsch (2009) state that non-governmental actors have the same impact as governmental actors in MLG of N2000. Such influence is reflected in the professionalization of the NGO sector in which, in the course of establishing MLG of N2000, experts and the public are included (Kapaciauskaite, 2011). Involving the public and NGO experts in accordance with the principles of the AC is necessary in order to establish MLG of N2000 (Hunka and de Groot, 2011). Experts play an important role in gathering information and making better decisions in the decision-making process (Holling, 1993). In many situations, they have the role of a lawyer to the public (usually in the process of access to justice). NGOs with experts involved have a crucial role in establishing MLG of N2000 through monitoring the proper implementation of international agreements into national law and their proper implementation in the field (such as the BD, HD and AC) (Christophersen and Weber, 2002; Cent et al., 2013).

\subsection{Contributions to the establishment of MLG of N2000 nature protection at the national level}

The transposition of the objectives and principles of nature protection with the EU level in accordance with the concept of SD at the national level leads to the greatest changes in the system of nature protection of Central and Eastern European (CEE) countries (Cent et al., 2014; Niedziałkowski et al., 2012; 2015). Wurcel (2008) states that the implementation of the $\mathrm{BD}, \mathrm{HD}$ and $\mathrm{AC}$ into national legislation contributes to the legitimacy of nature protection at the national level. Stringer and Paavola (2013) state that the establishment of N2000 contributes mostly to the development of the AC in practice which Lukšič (2002) points out as the main prerequisite to achieve the obje-

6 Lukšic $(1999,2001)$ described the challenges of democracy with the development of technology. In his book and article he cites the implementation of the $\mathrm{AC}$ as a fundamental (democratic) precondition of environmental protection (nature protection) in accordance with the concept of SD. 
ctives of nature protection at the national level in line with the concept of SD globally. The AC represents the involvement of non-governmental actors in the N2000, and in this way it leads to the development of participation in MLG of nature protection (for instance Poland, Italy, Greece, Romania and Hungary; see Ferranti et al., 2010; Apostolopoulou et al., 2012; Stringer and Paavola, 2013; Cent et al., 2014; Niedziałkowski et al., 2015). Increased participation in the establishment of MLG of N2000 has become the central component of the system of nature protection of CEE countries (Schusler et al., 2003; Ferranti et al., 2010; Cent et al., 2014; Kay, 2014; Niedziałkowski et al., 2015). Kluvánková-Oravská et al. (2009) suggest that the participation and involvement of non-governmental actors in nature protection contributes to the development of democracy in these areas.

\subsection{Research aim}

Niedziałkowski et al. (2015) states that it is important to distinguish between past experiences of implementation of N2000 (establishing MLG) that are based on rules and practices. The practices are quite different in all EU countries, and Fernández et al. (2010) associate it with the socio-political development of each country.

Fagan (2005, 2006a, 2006b, 2008, 2011); Fagan and Sircar (2010a, 2010b, 2012); Bojicic-Dzelilovic and Kostovicova (2013); Bache and Tomsic (2010); and Bache et al. (2011) carried out research on the impact of Europeanization in the countries of the former Yugoslavia and noted that there are common practices of non-compliance with international obligations and emergent national legislation in the process of Europeanization. Kay (2014) states that the countries of the former Yugoslavia represent a unique opportunity to explore the impact of Europeanization on the system of nature protection when establishing MLG of N2000.

The main objective of the research is to determine the influence of Europeanization on the nature protection system in the case of Croatia while establishing MLG of N2000. Such studies have not been performed in the counties of the former Yugoslavia, such as Croatia. The research of socio-political changes due to the impact of Europeanization in the national system of nature protection based on the objectives of $\mathrm{BD}, \mathrm{HD}$ and principles of $\mathrm{AC}$ contributes to the understanding of MLG of nature protection in this area which is a prerequisite of good governance (and management) within N2000 areas (Kati et al., 2014; Winter et al., 2014; Niedziałkowski et al., 2015) and to the development of the concept of SD (Ferranti et al., 2010; Winkel et al., 2015).

\section{RESEARCH FRAMEWORK AND METHODOLOGY}

\subsection{Research framework}

The research framework is set according to the morphogenetic model of Margaret Archer and includes three cycles, namely: structural conditionality, social interaction and structural reproduction (Figure 1). 


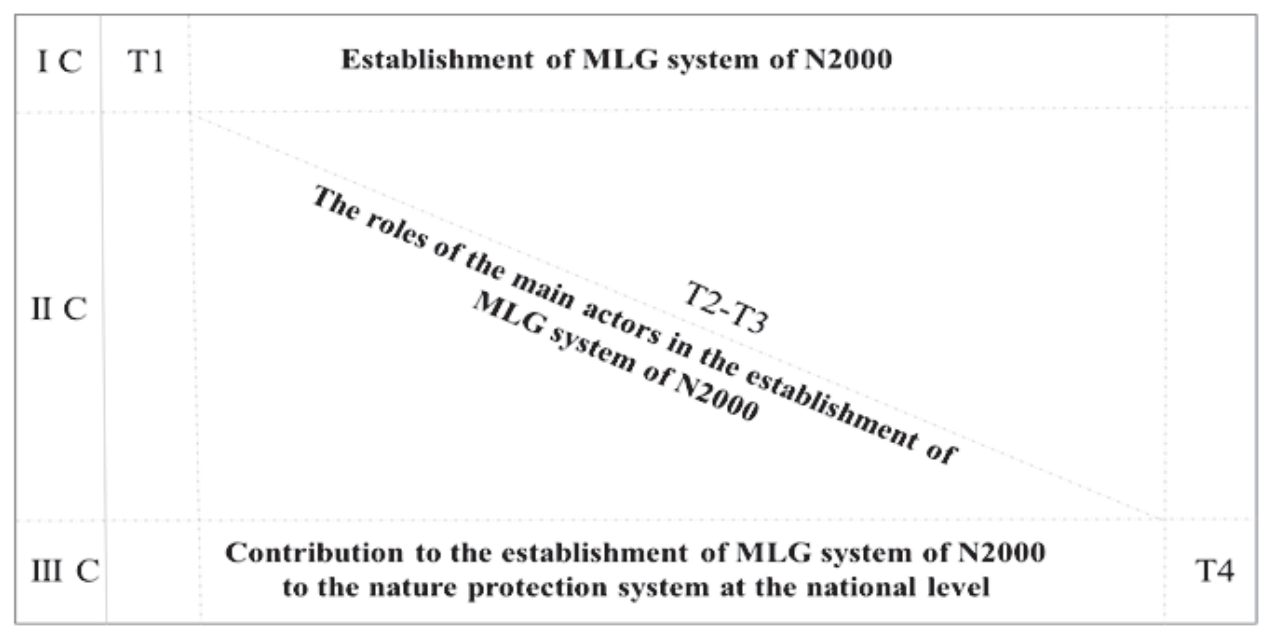

Source: Aleksandar Šobot, unpublished paper

Figure 1. Morphogenetic model of Margaret Archer customized for the research study

\subsubsection{First cycle: structural conditionality}

The first cycle, structural conditionality, is shown in the text through the influence of Europeanization on the system of nature protection in Croatia during the course of changing national legislation with the implementation of international commitments necessary for the implementation of N2000 (SD). Europeanization in Croatia was presented in the accession period, namely between the official candidacy to join the EU in 2003 up to its entry in 2013. International obligations during this period led to changing the concept of nature protection in Croatia, particularly through the implementation process of the objectives of the BD and HD, which represent two main pillars of N2000 areas which needed to be defined ${ }^{8}$ and adopted at the national level before accession to the EU. The BD and HD indirectly require the AC (Ferranti et al., 2010; Stringer and Paavola, 2013 Cent et al., 2014; Winter et al., 2014), whose principles are implemented into national legislation when establishing MLG of N2000 (Niedziałkowski et al., 2015). The AC introduces three new principles in the nature protection of SEE countries, namely: access to information, the opportunity to participate in decision-making, and access to justice (Lukšič 2002; Cent et al., 2014). The implementation of the objectives of these principles into national

7 Margaret Archer's morphogenetic model is specifically described in the following reference books: McAnulla (2005); Lukšič, (2009, 2010). This model is ideal for researching the impact of international aims of SD or environmental policy (such as AGENDA 21) upon national systems for protection of nature or environmental policy, in the implementation of MLG for protection of nature or environmental politics. 8 Areas defined according to the BD and the HD. 
legislation ${ }^{9}$ leads to a legislative definition of the main actors in nature protection at the national level and their new roles (Niedziałkowski et al., 2015). In the new Croatian legislation ${ }^{10}$ of EU nature protection, the competent ministry for nature protection, managers of protected areas (such as national parks), and NGOs (in the field of nature protection) become the main actors in nature protection. The newly created roles of the main actors of nature protection in Croatia are based mostly on the principles of the AC which is the basic change in the system of nature protection of SEE countries in the process of Europeanization. In this way, the AC became the main form of communication of all actors during the establishment of MLG of N2000. In such way, the influence of Europeanization on the nature protection system in these countries depends on the implementation of the principle of the $\mathrm{AC}$ (communication) by the main actors of nature protection in the process of establishing MLG of N2000.

The first cycle of studies includes two research questions. The first research question is to determine the process of establishing MLG of N2000 in Croatia that followed during the accession process. This research question describes projects that have contributed to the establishment of MLG of N2000. The main coordinators of projects, main activities, main objectives, organization, main participants, main financiers and their contribution in changing national legislation are determined within this question. The second research question is linked to the first research question in the context of legislation framework, namely to determine the changes in the national legislation during the implementation of N2000 international agreements. Within this research question the implementation of the $\mathrm{BD}, \mathrm{HD}$ and $\mathrm{AC}$ into national law is described with a focus on the newly created roles of major actors of nature protection in Croatia. ${ }^{11}$

\subsubsection{Second cycle: social interaction}

The second cycle, social interaction, is shown in the text describing the roles of the main actors who have had to establish MLG of N2000. The second cycle includes the research question: Determining the roles of the main actors in the process of establishing MLG of N2000. The role of the EU at the national level to establish MLG of N2000 is explored. At the national level, the role of the competent ministry for nature protection ${ }^{12}$ and the oldest protected area in the country, the Plitvice Lakes National Park (PLNP), is examined. National Parks (NP) for a long time were managers of protected areas and their role in the Europeanization and adoption of N2000 has become crucial for the performance

\footnotetext{
9 Implementation of the objectives is taken into account with the ratification of the AC in Croatia. Ratification of the $\mathrm{AC}$ at the national level obliges national governments to organize public participatory processes through the involvement of society in environmental issues (such as establishment of MLG of Natura 2000) (Stringer and Paavola 2013).

10 Current Croatian legislation.

11 The text relies on the current national legislation with any changes due to the process of establishing MLG of N2000.

12 The ministry in charge of nature protection in Croatia is the Ministry of Environment and Nature Protection. The Ministry of Nature Protection will be used as a notion in this text.
} 
of international obligations (BD and $\mathrm{HD}$ ) at the local level to the concept of SD (Ferranti et al., 2010). NP connect the supranational and national level of nature protection with the local level of nature protection and population of their area (Stringer and Paavola, 2013). Neuman (2005) states that the NP communication at all levels of MLG of nature protection is the key to the success of establishing MLG of nature protection (such as the establishment of MLG of N2000), and its further functioning. Geitzenauer et al. (2016) state that N2000 is a system of national parks of developed countries and because of this their role in MLG of N2000 has received a special focus in research. It investigates their communication and problems at all levels of MLG of nature protection in the process of establishing MLG of N2000. It also explores the role of non-governmental actors at the national level and of NGOs which, in the course of implementation of N2000, include the public and experts in the field of nature protection. Experts lead to more skilled labor and professionalization of NGOs in the field of nature protection (Börzel and Buzogány, 2010; Fernández et al., 2010; Kapaciauskaite, 2011; Kay, 2014).

\subsubsection{Third cycle: structural reproduction}

The third cycle, structural reproduction, includes the text which analyzes the main contributions of the entire process of establishing MLG of N2000 to the system of nature protection in Croatia on the principles of the $\mathrm{AC}$ and according to the objectives of the $\mathrm{BD}$ and HD. This cycle includes two research questions. The first research question is to determine the contribution of the process of establishing MLG of N2000 to the system of nature protection in Croatia. This issue will discuss how the ongoing Europeanization (establishing MLG of N2000) and the process of harmonization with EU national legislation, such as the implementation of the objectives of international agreements (BD, $\mathrm{HD}, \mathrm{AC})$, has contributed to the development of the nature protection system in Croatia. The second research question is identifying future challenges for the nature protection system in Croatia. This includes the most discussed problems in the execution of international nature protection obligations (AC) that are necessary for implementing nature protection goals (BD and $\mathrm{HD}$ ) in line with the concept of SD.

\subsection{Methodology}

The impact of Europeanization on the nature protection system in Croatia is investigated as a case study on the example of the establishment of MLG of N2000 in order to determine the socio-political changes in the nature protection system in Croatia. The implementation of N2000 is usually explored through a case study (Geitzenauer et al., 2016). The case study was performed according to Yin's (2009) case study research design steps. ${ }^{13}$

13 Yin's (2009) case study research design steps include: defining research questions, linking research questions, connecting with other issues necessary for the understanding of the responses from the research questions, connecting empirical data and theories in the interpretation of results. Linking empirical data and theories such as the instructions by Yin (2009) and their theory of inclusion in accordance with the research framework (morphogenetic model), research issues and major research aim. 
The data analysis of the results and the discussion ${ }^{14}$ is based on a desk study and qualitative research. The desk study includes documents (reports of implementation projects of N2000, national legislation relevant for nature protection, ${ }^{15}$ relevant governmental and non-governmental documents found on official web sites) and accessible references on establishing MLG of N2000 ${ }^{16}$ (relevant scientific papers in native and foreign languages). The empirical research is based on 16 interviews which were conducted with participants from the entire territory of Croatia at all levels of MLG of nature protection (local, national, supranational), and from the EU, governmental and non-governmental representatives as according to Robinson (2014). Snowball sampling ${ }^{17}$ is the chosen method of involving participants (conducting interviews) where each participant suggests a second person or institution that has participated in the establishment of MLG of N2000. That institution then further proposes a relevant person (participants in establishing MLG of N2000) for the interview. Also, interviews were conducted with residents of different ethnicity in Croatia, ${ }^{18}$ according to Robinson (2014). Interviews were conducted in the native language while one interview was conducted in another language. ${ }^{19}$

All interviews were conducted in the period from August 2014 to March 2016. Preparation of the interviews and the interviews themselves were conducted according to Torkar et al. (2011). An interview guide ${ }^{20}$ was developed within the project Multilevel Governance of Natural Resources in Slovenia, Croatia and Bosnia and Herzegovina, ${ }^{21}$ which is carried out in the framework of the Center for Political Theory, University of Ljubljana. The interview guide contains 41 questions $^{22}$ that contribute to the understanding of the establishment of MLG of N2000. The duration of the interview ranged from 35 minutes to 155 minutes.

14 The discussion has a transdisciplinary scope (or access) because it cooperates with four axioms according to Torkar and McGregor (2012). This transdisciplinary scope (or access) of the discussion is necessary because of the involvement of different stakeholders from different disciplines in the process of establishing MLG of N2000. Various participants contribute to the creation of a vision to establish MLG of N2000.

15 The Croatian Constitution, Law on Environmental Protection, Nature Protection Act, and National Strategy of Environmental Protection.

16 Keywords: Europeanization of South East Europe, accession process, Croatia, nature protection system, establishment of MLG of N2000.

17 According to Robinson (2014), snowball sampling has four steps.

18 According to the Croatian Constitution, there are 22 national minorities. Apart from Croatians, interviews were also conducted with Slovenians and Italians.

19 One interview was conducted in the Slovenian language (international expert).

20 The interview guide can be obtained on request via e-mail from the corresponding author.

21 The individual research project is part of the transdisciplinary project „Challenges of Democracy for the $21^{\text {st }}$ Century".

22 The questions are semi-open and should provide answers to five research questions set within the model of research. For instance, to obtain the answer to the first research question, questions such as: „When did the N2000 process start in your country?“, „What are the main phases in the process of establishing N2000 in your country?", etc. were asked within the interview; to answer the second research question, questions such as: „Were there any changes in the system for nature protection in your country, due to EU 'approaching'?", etc. were asked within the interview; to answer the third research question, questions such 
The transcription of the interviews was performed according to Torkar et al. (2011) ${ }^{23}$ and lasted from 50 to 180 minutes. All transcribed interviews were sent to the participants for review and confirmation and some 350 pages of text were collected altogether. On the basis of this a network of responses or matrix ${ }^{24}$ was made (Figure 2).

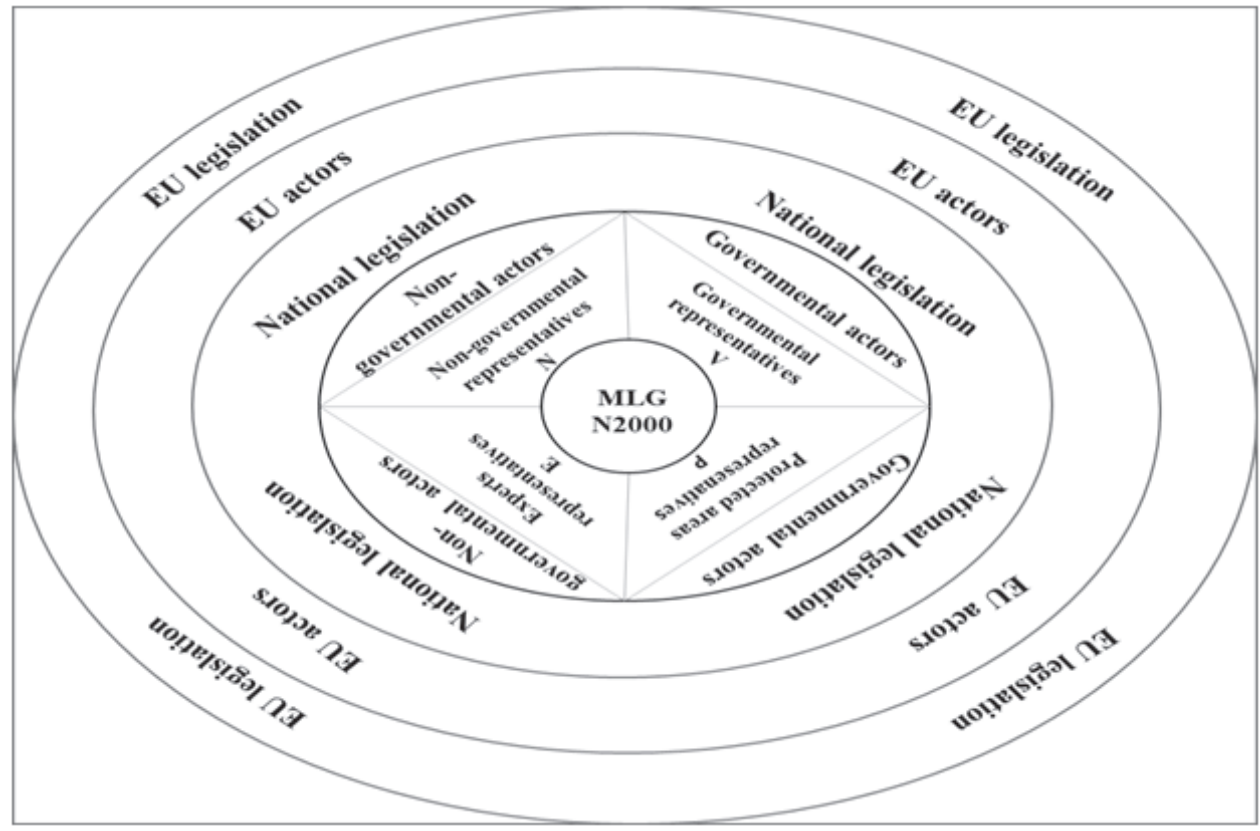

Source: Aleksandar Šobot, unpublished paper

Figure 2. Matrix of research

The matrix of responses of participants is divided into four groups, namely: representatives of governmental organization ${ }^{25}$ ( 4 interviews), representatives of protected areas ${ }^{26}$

as: „What was the role of EU in the process of establishing N2000 in your country?", „What was the role of the Ministry in charge for Nature Protection?", etc. were asked within the interview; to answer the fourth research question, questions such as: „What is the effect of establishing MLG of N2000 in your country?", etc. were asked within the interview; to answer the fifth research question, questions such as: „Future challenges of N2000 in your country?", etc. were asked within the interview.

23 Torkar et al. (2011) in their work present several quotes by other authors for the transcribing of interviews. It is very important to listen to the interview several times, and carefully write the answers to the research questions and research aim.

24 In preparing the matrix, citations were used according to Reisigl and Wodak's (2016) historical discourse analysis and previous studies of similar items, such as Lukšič (1999).

25 Four interviews were conducted with governmental representatives who come from the competent state ministry for nature protection (2) and the Institute for Nature Protection (2).

26 Three interviews were conducted with representatives of protected areas: Paklenica NP, Krka NP, Velebit NP. 
(3 interviews), representatives of the experts ${ }^{27}$ ( 4 interviews), representatives of $\mathrm{NGOs}^{28}$ (5 interviews). All interviews were conducted according to the instructions of Robinson (2014) concerning the confidentiality of data where the answers are coded according to the representatives of the groups and the order of interviews. In this way, the representatives of governmental organizations received the code $\mathrm{V}$ and serial numbers from 1 to 4; representatives of protected areas were given the code $\mathrm{P}$ and the numbers from 1 to 3; representatives of the experts were given the code $\mathrm{E}$ and numbers from 1 to 4 ; and representatives of NGOs have the code $\mathrm{N}$ and numbers from 1 to 5 . These groups also constitute representatives of the profession, the public and politics as well as major governmental and non-governmental actors in the process of establishing MLG of N2000 in Croatia. In addition, the process of establishing MLG of N2000 at a supranational level to involve EU actors that influence the national level to establish MLG of N2000. EU actors and EU legislation, governmental and non-governmental actors and national legistlation are starting point of establishing of MLG system of N2000 (Figure 2). That is why results and discusion ${ }^{29}$ are led from the position of legislation and main actors (or participants).

\section{RESULTS AND DISCUSSION}

\subsection{Process of establishment of $M L G$ of $N 2000$}

The Republic of Croatia (RC) has an area of $56542 \mathrm{~km}^{2}$ with close to 4000000 inhabitants. Croatia is a unitary and indivisible state in accordance with the Constitution (Article 1/RC Constitution). In addition to Croats, there are still 22 national minorities $^{30}$ who have their guaranteed representatives in the Parliament. ${ }^{31}$ The Parliament is the legislative body of the RC (Article 71/RC Constitution) and the law enactor (Article 81/RC Constitution). The draft law on adoption comes from the Government (Article 113/RC Constitution). The Government of the Republic of Croatia consists of a president and ministers from 20 ministries (Article 109/RC Constitution, source: Croatian Parliament, 2010). The legislation of the RC must implement international obligations of which it is a signatory (Article 141/RC Constitution). In Croatia international agree-

27 Four interviews were conducted with representative of the academic community including University of Zagreb, University of Split, University of Karlovac, and the Croatian Natural Museum.

28 Five interviews were conducted with representatives of NGOs in the field of nature protection in the whole Croatian territory, namely: BIOM, Green Action, Henrich Boll Stiftung, Friends of the Earth Europe, Zelena Istra.

29 The results and discussion were conducted according to the statements of participants of MLG and access to relevant reference books.

30 Serbs (3 representatives); Italians (1 representative); Hungarians (1 representative); Czechs and Slovaks (1 representative); Austrians, Bulgarians, Germans, Poles, Romas, Romanians, Ruthenians, Russians, Turks, Ukrainians, Vlachs, Jews (1 representative); Albanians, Bosnians, Montenegrins, Macedonians, Slovenians (1 representative).

31 They have eight representatives in the National Parliament. 
ments, according to legal force, are above the law of the $\mathrm{RC}$ and as such are invariable (Article 141/RC Constitution). Many international obligations were signed during the course of Europeanization, i.e., during the period of EU integration. In 2003 Croatia made a formal bid for entry into the EU and formally joined the EU in 2013. One of the conditions that had to be met along the way was the implementation of N2000 and required the establishment of MLG of N2000 (Cent et al., 2014; Niedziałkowski et al., 2015). In 2003 Croatia began the process of establishing MLG of N2000 in parallel with the process of its candidacy for EU membership. The first steps were the implementation of the objectives of the BD and HD into national legislation (V1, V2, V3, P3, N2, E4). Following this was the first project of National Ecological Network - important bird areas in Croatia, which lasted from the end of 2002 to the middle of 2005 (State Institute for Nature protection, 2016) and which was financed by the Croatian Government. This project was coordinated by the State Institute for Nature Protection ${ }^{32}$ (SINP), which was founded in $2002^{33}$ primarily for the professional tasks in the process of establishing N2000. ${ }^{34}$ The project included the first screening of all previous data, collecting data from literature and research in the field. Important bird areas were investigated in Croatia. On the basis of this project the first draft of the national ecological network was made.

During this project, the need for the adoption of the principle of the AC according to the models of other countries that had established MLG of N2000 was recognized. The AC was ratified in 2007 into the Croatian legislation..$^{35}$ Its objectives were implemented in the Law on Environmental Protection (LEP) (Croatian Parliament, 2013a) and the Law on Nature Protection (LNP) (Croatian Parliament, 2013b). Legal bases gave access to information, ${ }^{36}$ opportunities to participate in decision-making ${ }^{37}$ and access to justice $^{38}$ to governmental and non-governmental actors. These legal bases led to the establishment of a legislative framework of MLG of N2000 in Croatia. After the ratification of the AC in 2007 (Government of the Republic of Croatia, 2007), the first national

32 This institute was merged into a single body with the Agency for Protection of Nature in Croatia in 2015, named as the Croatian Agency for Environment and Nature Protection which is under the authority of the Ministry for Environment and Nature Protection.

33 The State Institute for Nature Protection was established by the Croatian Government in accordance with the Implementation Plan of the Stabilization and Association Agreement, which the Croatian Government and the European Union signed in 2001. The Institute began working in 2003.

34 At the beginning of the process the participants from the Ministry were responsible for nature protection.

35 The Convention on Access to Information, Public Participation in Decision-making and Access to Justice in Environmental Matters was confirmed in 2006 by the Croatian Parliament. In 2007 a new law was created to protect the environment within which these objectives were implemented.

36 Article 5, Article 6, Article 13, Article 198 (LNP); Article 17, Article 154, Article 155, Article 156, 157 (LEP).

37 Article 6, Article 199 (LNP); Article 15, Article 17, 162, Article 163, Article 164, Article 165, Article 166 (LEP).

38 Article 19, Article 167, Article 168, Article 172 (LEP). 
ecological network of Croatia was adopted. This network represents a further basis of the entire process of establishing MLG of N2000.

The project entitled „Institutional strengthening and implementation of the Natura 2000 network in Croatia" (State Institute for Nature protection, 2009) took place from 2008 to 2009 . This is the first project funded by the EU in the field of nature protection. The main objective of the project was to strengthen the Croatian nature protection sector. This project was marked as the first great period of employment, and strengthened the capacity of the nature protection sector, improving cross-sectoral cooperation, establishing communication with all important stakeholders at all levels of governance. The competent ministry for nature protection was formally responsible for the project. During this period (2009) Croatia also adopted the strategy of SD (Croatian Parliament, 2009) in which all the important goals of nature protection were integrated. ${ }^{39}$ The next project entitled „The identification and establishment of marine part of the Natura 2000 network in Croatia" (State Institute for Nature protection, 2011) took place from 2010 to 2011 . This project was also funded by the EU. The main objective of the project was the development of an ecological network of marine areas according to the objectives of the HD. The project also included the strengthening of inter-sectoral cooperation in the transfer of information. The project leader was SINP together with other consulting firms.

The latest project entitled „Capacity building for the preparation of management plans and strengthening of nature protection inspection on the proposed Natura 2000 areas" (State Institute for Nature protection, 2013) was implemented in the period from 2011 to 2013 and funded by the EU. The main objectives of the project were the final transposition of the $\mathrm{BD}$ and $\mathrm{HD}$ into the national legislation. In addition, the project was also aimed at informing the public about the importance of N2000 areas. The main coordinator of the project was the competent ministry for nature protection. In this period the experiences of Slovenia were used quite often (V1, V3, P1, P3, E1). The SINP of Slovenia was paid by the RC to organize a few introductory workshops on the topics of the final definition of N2000, establishing management and monitoring of N2000 areas (E1).

\subsection{Main actors in the new system of nature protection in Croatia and their new roles}

The national legislation on which nature protection is based is defined in accordance with the objectives of SD. Article 15 (LNP) states that the State shall cooperate with the $\mathrm{EU}$ in accordance with international agreements, i.e., that the international exchange of information is necessary. In this way the EU has been given the role of information transferor and coordinator of the implementation of international treaties into the national legislation.

39 Article 10 (LNP) and Article 50 (LEP) state that this strategy is the fundamental document of nature protection as it provides long-term objectives and guidelines for biodiversity. 
The Ministry of Nature Protection (Ministry of Environmental and Nature Protection) is directly responsible for communication with the European Commission in Croatia (Article 38/LEP), which implements the policy in this area at the national level. According to Article 13 (LNP), the ministry performs administrative professional activities, ${ }^{40}$ which represents the transposition of international goals (Article 35/LEP) and professional work in the process of establishing MLG of N2000. The work of the ministry is based on the principles of the AC (Article 154, 156, 162, 163, 164/LEP and 198, 199/ LNP). In addition to the relevant ministry, the law on environment protection (Article 34) defines the managers of protected areas (NP) and NGOs as major actors in nature protection.

According to Article 56 (LNP) and Article 57 (LNP), NP manage the ecological network in their territory. According to Article 131 (LNP) they have the role in collecting data and monitoring. NP have a scientific purpose (according to Article 113/LNP) and their activities (as public institutions) comply with the AC principles (Article 154, 156, 162, 163, 164/LEP and 198, 199/LNP).

Article 34 (LEP) defines that NGOs participate in the environmental protection and sustainable development as the main actors at the national level. They have the obligation to provide information and public involvement in decision-making (Article 165, 166/ LEP) during the assessment of the impact on the environment (and nature protection).

\subsection{Roles of the main actors in the establishment of MLG of N2000 in Croatia}

\subsubsection{Role and contribution of international actors / EU in the process of establishing $M L G$ of $N 2000$}

The EU provides leadership in the global governance of nature protection (Brown, 2013). In recent years it has significantly increased its institutional capacity for nature protection through expansion to the SEE countries. It has become a state actor (Mertens, 2013) in these countries because it has funded most and coordinated in an advisory capacity the implementation of EU objectives and the principles of nature protection in national legislation (Stubbs, 2005; Wurzel, 2008; EEA, 2010; Ferranti et al., 2010; Mertens, 2013; Kati et al., 2014). In Croatia, the EU funded and coordinated in an advisory capacity all projects to establish N2000 (V1, V2, V3, P1, N1, N2, E1, E2, E3). Through these projects, the implementation of the objectives of the $\mathrm{BD}$ and $\mathrm{HD}$, as well as $\mathrm{AC}$ objectives that represent the basic change in the system of nature protection in Croatia were realized. Funding by the EU secured most of the introduction of the legal order in the field of nature protection through the implementation of international commitments (V3, P1, N1, E1, E2). The EU is the guardian of international objectives of nature protection at the national level (Jordan, 1998).

40 The SINP (Article 14 and 15/LNP) performs professional work in the eco-network (N2000). Today the SINP cooperates within the Agency for Environment and Nature Protection, and the Ministry of Environmental and Nature Protection. 
In Croatia, the EU has been recognized as the guardian of the objectives of the agreement in order that they remain unchanged under the influence of domestic legislation (V1). In this way, supranational rules with a supranational participant secured the transparency and immutability of the rules of nature protection at the national level. The immutability of the $\mathrm{AC}$ rules led to altering public awareness and former practices. According to Ferranti et al. (2010) and Torkar (2014), the change of consciousness is the basis for the introduction of new practices (pro-environmental) to the concept of $\mathrm{SD}$. The new practice in Croatia has demanded changes in the system of nature protection, and system access through planning and cross-sectoral cooperation which had not been the practice earlier. Beunen and de Vries (2011) state that the EU requires the planning of nature protection while Kapaciaskaite (2011) states that the involvement of the EU leads to increased cross-sectoral cooperation. This is why the NGO sector for the first time gained equality in decision-making in the field of nature protection as the EU ensures the equality of actors (Newig and Fritsch, 2009). In Croatia this is apparent in the substantial change in the relationships of governmental and non-governmental actors in the nature protection system. This has led to increasing the number of participants in the nature protection system, to showing respect for all actors in decision making, as well as to a greater respect for legislation. The EU is the guardian of rights (Jordan, 1998) and all disputable situations that have come between governmental and non-governmental actors in the process of establishing N2000 have led to the freezing of funds for Croatia (V3). This is the mechanism by which the EU does not participate directly in the relations between stakeholders (governmental and non-governmental actors) but protects supranational interests and compels participants to work together to find a solution.

In many countries the EU represents a platform of knowledge transfer between member states (Jordan et al., 2000; Giljum et al., 2005; Brulle, 2010) and in Croatia the EU has become a national consultant for all future plans of nature protection which must comply with the ranking of EU legislation, i.e., of other member states. In this way, a new practice in the transfer of information was introduced which has been recognized as important in all processes of nature protection.

\subsubsection{Role and contribution of governmental actors / competent ministry for nature prote- ction in the process of establishing MLG of N2000}

Weber and Christophersen (2002); Lockwood et al. (2009); and Ferranti et al. (2010) state that governmental institutions are responsible for communication at the international level and for implementation of international legislation into national legislation (such as the BD, HD, AC). Bulkeley and Mol (2003); Neumann (2005); Beunen and de Vries (2011); and Cent et al. (2014) state that governmental institutions are responsible for organizing the process of establishing MLG of N2000, and for collecting information and the involvement of all actors in decision-making. The competent ministry for nature protection in Croatia had a formal organizational role in the processes of N2000. The main role of the ministry was of an administrative nature (implementati- 
on of the AC), while the SINP41 was established for the needs of professional work on N2000 (gathering information). The SINP, on behalf of the competent ministry for nature protection, performed all the tasks related to N2000 (N1, E1, E2). Together with representatives of the Ministry, all the processes of establishing MLG of N2000 under this Ministry were organized. The first steps on the projects to establish N2000 led to the creation of the first ecological network at the national level. The entire process of research was coordinated by representatives of the SINP while the process of involving non-governmental researchers was coordinated by the competent ministry (V1, V2, P2, P3, N1, N2, E1, E2, E4). The Ministry did not have a working group on N2000 as was the case in other countries (such as Slovenia) and N2000 was organized on a project to project basis. The Ministry worked according to the current politics, which was changed on several occasions and led to a delay in the establishment of N2000 which affected the continuity of work. The problem of intermittent work on the establishment of N2000 is that it is quite dependent on legal forms and financial resources (Stringer and Paavola, 2013). After signing the AC (establishment of legal forms) and obtaining the first major funding from the EU, the processes of establishing MLG of N2000 were divided into three formal projects. These processes demanded increased cross-sectoral cooperation and the involvement of non-governmental actors.

Cross-sectoral cooperation is the basis of the implementation of the objectives of SD at the institutional level (Dietz et al., 2003; Ostrom, 1990, 2005). Other sectors were included through their management plans into which they had to integrate the objectives of the national eco-network (V2, P3, N1, N2, E1, E2, E4). Statutory laws were changing gradually which obliged other sectors to take the nature protection sector into account. This legislation related primarily to the environmental impact assessment (EIA), namely the assessment of impact on nature. The RC had begun working on this since 2007 (E2). In this way, different sectors were involved in the public debate on the issue of projects which may have an impact on nature. The competent ministry began to involve other sectors for their opinion and eliminating problems towards achieving the objectives of nature protection (V3). Along with this there was also a certain harmonization of laws with the laws of nature protection ${ }^{42}$ according to EU requirements. The greatest collaboration was with the Ministry of Agriculture (the forestry sector, agriculture and water management), because large areas of forests, agricultural land and water areas fall under N2000 (V2, P2, P3, N1, N2, E2). The forestry sector was very actively involved in the process of establishing MLG of N2000. The Board of forests was founded in 2009, within which representatives of state forests, representatives of private forests and representatives of nature protection were included in order to determine the entire territory and coordinate with N2000 (V1). Private forest owners were

41 The SINP was initially a part of the Ministry of Culture, however, very soon it was concluded that its role falls primarily under the jurisdiction of the Ministry of Environment and it was transferred there (E1, E2).

42 An example is the Water Act which implemented the objectives of the Water Framework Directive. 
not eager to accept N2000 as in this way they would have fewer privileges on their property. Their primary goal was profit and that caused a major problem. However, by 2013 (with the adoption of N2000) all ambiguities were clarified through discussion where foresters saw the benefits of N2000, and accepted this network (V1). The discussion was the basis for resolving ambiguities in the process of the creation of N2000 and any future potential problems (Torkar and McGregor, 2012).

As the agricultural sector was not effectively involved in the process of establishing MLG of N2000 (V1, E2), according to Rosa and Da Silva (2005) and Kay (2014) in the later stages (such as the management of N2000) this can lead to problems. V3 stated: (...) There were no representatives of the agricultural sector at the meetings of N2000 (...). Agriculture in the RC has several large multinational companies which face an intense exploitation of land ${ }^{43}$. Their political influence is quite large and this has led to poor involvement of the agricultural sector in the process of establishing MLG of N2000 ${ }^{44}$ $(\mathrm{N} 1, \mathrm{P} 2)$. With that sector better networking and communication was needed in order to discuss all disagreements and solve all future potential problems. In addition, all other sectors were marginally involved and did not have enough information about N2000 (N1).

\subsubsection{Role and contribution of the PLNP in the process of establishing MLG of N2000}

The PLNP is the oldest protected area in the country and its area covers 27.685 ha. The first research and protection of this area was carried out in 1926 and in 1949 this area was declared a National Park. The territory of the park includes four ${ }^{45}$ municipalities and the administrative council and director carry out the park management. ${ }^{46}$ The governing council is comprised of four members appointed by the competent Minister. The management of PLNP has no representatives of municipalities, representatives of the land owners or representatives of NGOs.

The PLNP did not have a defined role in establishing MLG of N2000 by the competent Ministry. According to national legislation and the concept of SD (from the BR), NP should work on collecting information and involving local people in decision-making. $\mathrm{NP}$ represent a territory with private land owners from the previous period (Neuman, 2005) and in the establishment of MLG of N2000 there is increased participation in these areas (Niedziałkowski et al., 2012; Stringer and Paavola, 2013). Also, according to the national legislation, the activities of collecting information (such as public opinion), of raising public awareness and of public involvement in decision-making need to be planned. The opinions of these areas are very important as people often see N2000 as a system of nature protection in national parks (Neuman, 2005; Romano and Zullo, 2015; Geitzenauer et al., 2016). According to the concept of SD (from the BR) and

\footnotetext{
43 One such example is Agrokor.

$44 \mathrm{~V} 2$ stated that low commitment of the public to join the EU (about 52\%) contributed to this.

45 Plitvice Lakes and Vrhovine (Lika-Senj Country); Saborsko and Rakovica (Karlovac Country).

46 In accordance with Article 13 of the Statute of the PLNP, source: Plitvice Lakes National Park, 2014.
} 
according to Rosa and Da Silva (2005) and Jones et al. (2012), such opinions are the basis of information for management of nature protection. Opinions on protected areas (N2000 areas) in the PLNP were not collected in the process of establishing MLG of $\mathrm{N} 2000$ and it is one of the major flaws of the organization of the entire process ${ }^{47}$. In the future it will be necessary to collect the opinions of inhabitants of protected areas of nature protection and of N2000 with the goal of long-term (potential) conflict resolution, which will also contribute to increasing public involvement in the operation of the park. Work on the collection of opinions can lead to altering the behavior of private land owners to sustainable land use in NP (Rosa Da Silva, 2005; Niedziałkowski et al., 2012; Kay, 2014) and this has been proven in the course of establishing MLG of N2000 in Slovenia.

The PLNP worked on the media promotion of N2000 (V2, N2) which Ferranti et al. (2010) considered as very important in raising public awareness. NP (such as PLNP) invest a lot in tourism promotion and N2000 comes as an additional brand. In this way they have contributed significantly to the public promotion of N2000. However, the problem is that the media knows very little about nature protection and of N2000 (E2). Therefore, the promotion of N2000 only took a very small part of the media space in relation to the promotion of the tourist offers of the parks. The media is also very susceptible to politics and politics is more in the interest of the promotion of tourism due to "profit" rather than to promoting further nature protection (such as N2000) (N2). The question of "profit" distribution arises from the revenues of the PLNP. There is no visible manner of restitution of these funds in the nature protection sector and it is necessary to work on this in the future. In this way, it would enable the de-politicization of "profit" from the revenues of NP of the RC.

The PLNP has been more a financial institution than an institution of nature protection since its creation $(\mathrm{V} 1, \mathrm{~N} 1)$ as it manages large financial potential based on tourism. Therefore, tourist pressure is very large and plenty of biodiversity is rather endangered (V2, E1). The management of tourists is one of the key problems within this $\operatorname{park}^{48}(\mathrm{~V} 1$, V2, V3, E1). It is necessary to establish acceptable limits of tourists which the parks in the RC do not have now in order to preserve biodiversity. Gathering information for the conservation of biodiversity through research of species inside the park is quite debatable. It is almost a common occurrence that „privileged“ groups of researchers can do research activities in the park (N1, E1). They receive a lot of money for monitoring and tracking species, but their data are very poorly accessible and sometimes not even published anywhere (N1). In this way, the "negligence“ of researchers can cause the

47 In this study, however, the opinions of participants were collected in the process of establishing MLG of N2000 about the importance of nature protection. Most participants recognized nature protection as part of legislation and the current national policy. In many cases N2000 was taken as a regimen mainly due to the politicization of nature and poor education, and poor long-term cooperation between the public and protected areas.

48 With the increase of tourists there is also the increase of traffic in the park. 
complete extinction of a particular species in the PLNP (P2). On the other hand, the $\mathrm{RC}$ does a competent inspection for nature protection (in accordance with Article 210/ LNP) but, E1 stated: (...) Inspections in PLNP are very rare (...) mostly because of political pressure (...) E2 stated: No one can control PLN (...). Proper inspection is one of the major problems that needs to be carried out in the future and NGOs should contribute to this. The relation between PLNP and NGOs during the establishment of N2000 was very authoritative, where it all came down to paying for „services“ such as gathering information (monitoring) which NGOs did for the park (V1, V2, P2, N1, E1, E2) according to the needs of N2000 and of the management plan. The park management plan is adopted every 10 years $^{49}$ and the last management plan was adopted in 2007. In the meantime, N2000 was adopted in the RC and it is debatable how PLNP performs activities related to the implementation of the objectives of N2000 at the local level (and the principles of the AC). They have integrated the measures of the national ecological network, however, the measures for N2000 are not clearly visible in the management plan from 2007. The annual management plan is not available on the website for the general public.

It is necessary to strengthen the PLNP professionally in order to meet the objectives of nature protection in accordance with the concept of SD. This needs to be done on a legal basis where the determined percentage of experts necessary for monitoring the state of the PLNP would be guaranteed by the law. Also, it is necessary to establish systematic research and monitoring with the help of the academic community, first of all higher education institutions through their regular activities, which is proposed by the concept of SD (from the BR). In this way, protected areas would be strengthened professionally, which would contribute to more expert debates with the local population, more transparency of data, and less politicization of nature protection.

At the national level, the PLNP had no significant role in the policy of the establishment of MLG of N2000 although Arnberger et al. (2012) cited it as its main role. The projects for the establishment of MLG of N2000 had no concrete plans of involving the PLNP in the entire process even though they represent long-term managers of protected areas, according to which N2000 was established, as Geitzenauer et al. (2016) stated. This is a problem on a legal basis. The law on the PLNP has no visible objectives of implementing the $\mathrm{BD}, \mathrm{HD}$ and the principles of the $\mathrm{AC}$. In the future it will be necessary to change this legislation with the implementation of the objectives and principles of N2000.

The PLNP has a cross-sectoral cooperation at the national level through management plans in its territory, mostly with the tourism, forest, and agriculture sectors (V1, P1). The collaboration with these sectors has become even greater in the process of establishing MLG of N2000, because N2000 requires the inclusion of the goals of nature protection in all sectors and their interconnection. The connection and communication

49 The PLNP Management Plan, source: Plitvice Lakes National Park, 2007. 
with other protected areas was rather poor until the beginning of the implementation process of N2000 and the processes themselves quite influenced the communication in becoming much better but the problem is that it is still not entirely present ${ }^{50}$ in practice. The SINP and competent ministries with which NP have a communication at the national level should work harder on it.

At the supranational level the PLNP is a member of the Association of Dinaric Arc Parks, which was established in order to transfer experiences. However, the PLNP did not record the transfer of experiences in terms of N2000. In addition, at the international level there is the problem of climate change (CC) which is scarcely regarded as a topic in the RC and very little is known about it. Climate change influence can be seen on vegetation itself but there are no relevant studies (N1). Also, CC together with water bodies caused great floods in the RC and changed certain areas. However, there is no policy in research or adaptation of such impacts and it is necessary to work more on this area in the future.

The main problem is that NP in the RC have no participatory management model (E2). According to the statute of the PLNP, the local population does not have its own representatives in the governing council of the park. Also, representatives of the municipalities do not have their representatives in the governing council of NP. The governing council of NP is appointed by the competent ministry and decisions are still quite centralized. In this way, the impact of politics (current) is quite immense in NP. This is one of the key problems. This results in that each change of the government causes the change of the director of the park (changes of management policy). It is necessary to establish new models of management of protected areas ${ }^{51}$ which would lead to ,greater democratization "52 of nature protection in which non-governmental actors (such as private land owners and NGOs) would be involved and have equal decision-making power in the management of the PLNP as governmental actors.

\subsubsection{Role and contribution of non-governmental actors / NGOs in the process of establis- hing MLG of N2000}

At the beginning of the process the competent ministry and the SINP organized the research of the potential N2000 areas and some experts from different fields were included in this research (V1, V2, N1, E1, E2, E4). In time, as the process continued and the

\footnotetext{
50 P2 stated: (...) In 2013 the eco-network of the NP of the RC was established which in practice does not work (...).

51Carlsson and Berkes (2005); Ferranti et al. (2010); Beunen and de Vries (2011) propose co-management; Niedziałkowski et al. (2012); Gruby and Basurto (2013); Blenckner et al. (2015) propose ecosystem management; Slocombe (1998), Imperial (1999); Borgström et al. (2015); Nilsson and Bohman (2015) propose ecosystem based management; Armitage (2005), Booth and Halseth (2011), Bennett (2016) and the concept of SD (from world conservation strategy (1980), source: IUCN, 1980) propose community based management.

52 Lukšič (2010) writes about the need for "greater democratization" based on the equal distribution of power in decision-making.
} 
EU funded more research, the experts organized their own research groups and started establishing their NGOs according to the needs of work on N2000 (V1, V2, E1, E2). Financing is the basis of the establishment and development of NGOs (Carmin, 2010). The key period for the establishment and development of the NGO sector was from 2007 to 2013 and in this period the EU significantly funded the research of potential N2000 areas in Croatia.

NGOs play a major role in gathering information (Weber and Christophersen, 2002; Hiedanpaa 2002; Oberthür et al., 2003; Kapaciauskaite, 2011; Cent et al, 2013; Stringer and Paavola, 2013; Cent et al., 2014; Kay 2014; Niedziałkowski et al., 2015) and in the RC there was more work on gathering information on important species and habitats for $\mathrm{N} 2000$ areas in this period. All this caused greater professionalization of the NGO sector in the field of nature protection. Carmin (2010); and Börzel and Buzogány (2010) state that the professionalization of NGOs led to their involvement in environmental politics and policy and in the RC this led to their involvement in environmental politics and policy at the national level where they primarily promoted (represented) the rights of the public. Hartley and Wood (2005) state that NGOs represent the rights of the public. The public until this period was not well-developed and it was often included in the NGO sector in order to act on the $\operatorname{problem}^{53}(\mathrm{~N} 3, \mathrm{~N} 4, \mathrm{~N} 5)$ because it realized that NGOs could get equality in decision-making as governmental actors. Newig and Fritsch (2009) state that in the process of N2000 non-governmental actors share equality in decision-making as governmental actors. The principles of the AC adopted in the establishment of MLG of N2000 contributed to this mostly. Their role at the national level was becoming visible for the media which began to increasingly monitor the activities of the NGO sector (V4, N3, N4, N5, E3). Rootes (2007) states that many NGOs attract media attention in this way.

Strengthening of NGOs at the national level led to a better connection with NGOs at the international level and a transfer of experiences during the establishment of N2000

53 On the other hand, the Government noticed an increasing number of NGOs established at the national level and experienced this as a „coup“. In 2007 there was the incident of illegal wiretapping of some NGO activists who received more media attention because of the public criticism of the poor attitudes of the Government towards the population (and nature) (N3). During this period, the NGO sector started to control the Government and submitted all the observed irregularities to the court. One such example was the Water Act. During the EU integration the Government adopted many laws under „urgency“ and there were great problems here as the general public was not well-informed (N3, N4, N5, E3). NGOs worked on educating and raising public awareness in order to build public understanding that some issues are vitally important, such as the Water Act (V4, N3, N5, E3). This was the law where many private interests were "wrapped" into the public domain and should be adopted without major considerations (N3, N4, N5). NGOs stopped the "emergency procedures" and did a lot of the work in the coming period to "keep" the law against private interests. In addition, in 2007-2008 there was a "right to the city “ campaign where the first street protests were organized by the NGO sector. With this, the NGO sector for the first time affected the raising of public awareness that they could and should be involved in decision-making. By that time, the public was very latent and did not think or feel that it could and should be involved in decision-making (V4, N3, N4, E3). 
at the national level (Kapaciauskaite, 2011) In the RC this strengthening of NGOs at the national level led to increased connections with international organizations (such as $\mathrm{BIOM}^{54}$ and Green Action ${ }^{55}$ ) resulting in the transfer of experiences and practices from other countries that had been members of the EU for a long time already. Such experiences contributed to the fact that at the first biogeographical seminars for N2000 in 2014, NGOs in the RC corrected the Government's proposal for N2000 areas. With the expert discussion they made a better proposal on the example of international experiences.

At the same time, this international connectivity contributed to linking up with global campaigns and this had an influence on improving the performance of the organization, increasing the expertise, and enhancing communication with other sectors involved in nature protection (N4, N5, E3). Also, those NGOs which were more present in Brussels gained a greater influence in lobbying at the international level regarding nature protection (E3). There was better communication at the international level and due to problems at the national level, many international organizations began to engage in problem solving ${ }^{56}(\mathrm{~N} 3)$.

The problems usually came up in the process of EIA. Krenova and Kindlmann (2015); Hartley and Wood (2005) state in the process of establishing N2000 NGOs were increasingly involved in the EIA. In that way they became a corrective factor and rejected many of the planned projects which were harmful ${ }^{57}$ to the planned N2000 areas. Sadeleer et al., (2002); Hartley and Wood (2005); Fernandez et al. (2010); and Borzel et al. (2010) suggest that the inclusion of NGOs in the process of EIA contributes much to the development of the judiciary in the field of nature protection.

After joining the EU and adopting N2000 the NGO sector gained great respect from the Government (V4). Also, there was a greater need for monitoring of N2000 areas. Many NGOs after the adoption of N2000 were given a significant role in monitoring (Cent et al., 2013). NGOs in the RC during the period of establishing MLG of N2000 were significantly professionalized (from the period when they were voluntary organizations) and they increasingly began to take over the duties of monitoring. On the other hand, this professionalization led to greater bureaucracy and NGOs became quite similar to public institutions making them against the primary objectives of nature protection (N5). Carmin (2010) mentions the problem of bureaucratization of NGOs. However, Reed et al. (2008) state that the professionalization requires experts in certain fields of nature protection, and this requires money, which gives them less flexibility. Often, large protected areas (such as the PLNP), which are in a very good financial

54 BIOM became a member of Bird Life International.

55 Green Action became a member of Friends of the Earth Europe and CEEWeb.

56 N3 stated: (...) the Ministry of Environment filed a lawsuit against Green Action for slowing the disposal of hazardous waste into the environment and the minimal fine was 50000 Euros. Within two days numerous international organizations were mobilized to put pressure on the Ministry to withdraw this lawsuit and the complaint was later withdrawn under the international pressure.

57 The upper flow of the Korana River. 
position, pay large sums of money for the services of NGOs in carrying out monitoring (V1, V2, P2, N1, E1, E2) and it often happens that such competitions are won by the „same organizations“ (N2, N3). Their monitoring is often not visible and the results are used for "greenwashing" compared to what they earn (E1). In this way, some NGOs have become very financially strong and their leaders have begun to enjoy the reputation of "parallel political elite“ and they often become partners with politics and separate from the public and the primary objectives for which they were established (N4). Such situation has led to a disproportionate growth of the NGO sector in the RC. At the national level there are several major NGOs which take all the major projects, and at the local level there are thousands which are still voluntary (N5, E3). Therefore, it is necessary to create a strategy of balanced development of the NGO sector in the territory of the entire country in the future.

\subsection{Contribution of Europeanization to the nature protection system in Croatia in the case of establishing MLG of N2000}

The transposition of the objectives and principles of nature protection from the EU level at the national level leads to the greatest changes in the nature protection system of SEE countries (Cent 2014). In the RC the transposition of the BD, HD and AC principles contributed to major changes in the nature protection system. The environmental law serves as a central component of the nature protection (Holing, 1993). The implementation of international obligations has contributed to the introduction of the nature protection system at the national level in line with the concept of SD. Wurcel (2008) stated that the implementation of the BD, HD and AC into national legislation contributes to the legitimacy of nature protection at the national level. Stringer and Paavola (2013) state that the establishment of N2000 mostly contributes to the development of the AC principles at the local level towards achieving the objectives of nature protection at the national level in accordance with the concept of SD at the global level. The AC has become a central component of the nature protection system of the RC. Kluvánková-Oravská et al. (2009) suggest that the processes of establishing N2000 contribute to gathering information according to the $\mathrm{BD}$ and $\mathrm{HD}$; the involvement of governmental and non-governmental actors in nature protection in line with the objectives of the $\mathrm{BD}$ and $\mathrm{HD}$; and lead to the development of the judiciary in nature protection in line with the $\mathrm{BD}$ and $\mathrm{HD}$.

\subsubsection{The contribution of the first pillar of the $A C$ according to the $B D$ and $H D$}

The processes of establishing N2000 contribute to the organized collection of information in line with the BD and HD (Kati et al., 2014). In the RC the process of establishing MLG of N2000 has led to the increased information on the number and status of species in the whole country as well as their value in relation to other countries. Kay (2014); and Romano and Zullo (2015) state that the increase of information (according to the $\mathrm{BD}$ and $\mathrm{HD}$ ) leads to a greater protection of species and habitats at the national level through the establishment of new protected areas (potential N2000 areas). New 
protected areas have also been established in Slovenia where one third of the country is protected by the $\mathrm{BD}$ and $\mathrm{HD}$. Also, in the $\mathrm{RC}$ new protected areas were established where one third of the country is protected by the BD and HD.

Niedziałkowski et al. (2015) report that gathering of information contributes to the development of cross-sectoral cooperation. Gathering information about the N2000 habitats and species in the RC has led to increased cooperation and communication in nature protection in all sectors. This in turn led to the changes of sector policies during the implementation of the BD and HD objectives (objectives of SD). Kluvánková-Oravská et al. (2009); and Kay (2014) report that the implementation of the BD and $\mathrm{HD}$ in all sectoral policies leads to the decentralization of the nature protection system at the national level that causes institutional transformation. In the RC, in the course of establishing N2000 institutional transformation occurred. The competent ministry changed its own internal structure, and the SINP was founded as a professional institution working on collecting data for N2000. The SINP has an obligation to publish all relevant information related to the N2000 areas. In this way for the first time in the RC public access to information in the field of nature protection was enabled in one place which, according to EEA (2010), represents the basis for halting the loss of biodiversity.

\subsubsection{The contribution of the second pillar of the $A C$ according to the $B D$ and $H D$}

The process of establishing N2000 requires public participation (Stringer \& Paavola, 2013; Cent et al. 2014; Kati et al., 2014; Niedziałkowski et al., 2015), as was the case during the entire process of establishing MLG of N2000 in the RC, and it contributed to changing the practices of the public from being passive observers to active participants. Public participation in decision-making contributes to the development of participation in nature protection (Cent et al., 2014). For the first time governmental and non-governmental actors (the public, the profession and politics) created the policy of nature protection together in the territory of the entire country, which led to the development of participation in the nature protection system of the RC (i.e., changing its earlier practice). The development of participation of non-governmental actors contributed to the development of democracy (Kluvánková-Oravská et al., 2009).

The establishment of N2000 is the first major period of participation in nature protection of the RC. Weber and Christophersen (2002); Cent et al. (2013) suggest that an increase in participation usually goes through NGOs. In the RC NGOs contributed to the increase in participation mostly in the field of nature protection. NGOs included all the interested public in decision-making when establishing MLG of N2000. That is why the NGO sector in Croatia experienced an „evolution“" in its development. For the first time in the nature protection system in Croatia public participation is understood as the ability of protecting nature. Torkar and McGregor (2012) state that the understanding of nature protection (raising public awareness) is the basis for changes in thinking and behavior and such changes, according to Gifford and Nilsson (2014); and Torkar (2014), are the basis for SD. 


\subsubsection{The contribution of the third pillar of the $A C$ according to the $B D$ and $H D$}

Cent et al. (2013) state that public involvement goes through NGOs while Grodzinska-Jurczak and Cent (2011) suggest that the public is involved in NGOs in order to act on the problem. Hartley and Wood (2005) report that public involvement in NGOs is the largest in the process of the EIA whose directives are implemented in the national legislation in parallel with the $\mathrm{BD}$ and $\mathrm{HD}$. In the $\mathrm{RC}$ the public has recognized the possibility for action on the problem in nature protection through NGOs that received similar impact as governmental organizations and partly included them in the process of EIA. Therefore, NGOs launched many lawsuits against harmful projects in the proposed N2000 areas (that ended up at national or EU courts) (N1, N2, N3, N4, N5). This led to the development of the judiciary in nature protection in Croatia.

\subsection{Future challenges of the nature protection system}

The management plan of N2000 at the national level has not yet been adopted after four years from the adoption of N2000. Performing the BD and HD objectives according to the principles of the $\mathrm{AC}$ in practice is almost non-existent in protected areas which are managers of N2000 areas (such as the PLNP). In addition, at the local level new protected areas were established that need to have the function of management of N2000 areas (the same as of the NP). It is debatable how their future work will be like due to the current practice (non-participation of the public, such as in NP), lack of connection of protected areas (without the exchange of experience), political influence (which appoints the directors), the problem of financing monitoring (protected areas depend on the budgets of municipalities), the problem of capacity for monitoring (protected areas do not have a sufficient number of employees) and reporting (because the state is obliged to provide reports to the EU). Also, performing the objectives of the $\mathrm{BD}$ and $\mathrm{HD}$ according to the principles of the $\mathrm{AC}$ in practice seems problematic for Croatia.

\subsubsection{The challenge of the first pillar of the $A C$ according to the $B D$ and $H D$}

At the local level it is necessary to work more on collecting the opinions of the population on nature protection and of N2000 in protected areas (such as the PLNP) and on raising public awareness that will lead to more professional discussions and elimination of potential conflicts and problems, such as private property in N2000 areas. This has not been done so far in nature protection in Croatia and N2000. Such jobs are provided according to the concept of SD (from the BR) and Ferranti et al. (2010); Niedziałkowski et al. (2012); and Stringer and Paavola (2013) consider it very important. Data on opinions is necessary to integrate into the communication in the field of nature protection which is required in order to develop in the future as an independent document at the state level. Also, data collection can be arranged through the ongoing program of e-participation for all interested public ${ }^{58}$ of N2000 areas. In this way, all the inhabitants

58 In many developed countries evidence-based monitoring programs are highly developed and they contribute to the community-based management. 
of protected areas could publicly participate in the gathering of information for the proper management of the area and contribute to communication in nature protection. At the national level there is the problem of incomplete information by competent institutions (ministries) and what Booth and Halseth (2011) consider as the greatest challenge in nature protection at the national level. The problems are mainly in the lack of connection and lack of transparency with all local, national and regional data. This creates challenges in the future which have to be based on greater public involvement in gathering information, and the necessity to ,institutionally upgrade“ public institutions. It is essential to include the whole of society to gather information ${ }^{59}$ in order to achieve full nature protection. In the first line there the academic community (higher education institutions) should be included to collect information and regular monitoring of habitats and species, which the concept of SD (from the BR) suggests. Since many universities have programs for nature protection this can be included as part of their regular activities. ${ }^{60}$

At the international level, the greatest challenges are monitoring the impact of CC on species and habitats in protected areas (Dimitrakopoulos et al., 2010; Blenckner et al., 2015). The impact of CC on protected areas in Croatia is of very little extent or it is not investigated at all. In the future it is essential to approach this problem in a more organized way with making policies of adaptation and management of such changes in line with the international practice.

\subsubsection{The challenge of the second pillar of the $A C$ according to the $B D$ and $H D$}

One of the key problems is the unequal representation of NGOs from the entire territory of the RC in nature protection politics and policy which Newig and Fritsch (2009); and Cent et al. (2013) consider as crucial. It is necessary to work on the organized development of the $\mathrm{NGO}$ sector (in the field of nature protection) on the entire territory of the RC in order to enable non-governmental actors from peripheral areas to become more involved in decision-making.

Also, at the national level in the $\mathrm{RC}$ there is the problem of intermittent and unequal public participation. There is no uniform standard with respect to the $\mathrm{AC}$ in all of the $\mathrm{RC}$ as they are mostly performed on a case-by-case basis. ${ }^{61}$ Unequal performance of public participation in decision-making with an equal standard of respect for the law on the entire territory of the RC is something that becomes a need and a challenge in the future.

59 Rosa and Da Silva (2005) suggest that in the monitoring of birds in France 200000 volunteers take part. 60 It is especially important that the education of N2000 should be integrated into the regular agricultural education which has not been the case at all at higher education institutions in Croatia.

61 N2 stated: „(...) For example, some sectors that are under great public pressure are forced to follow the Aarhus Convention at a high level and those that are not under great public pressure do not follow the Aarhus Convention at a high level, but they work just as a 'meeting the form' (...)“. 
Another problem is the inconsistency of all sectors in the implementation of the objectives and principles of nature protection in what Zito (2005); Lakićević and Tatović (2012); Niedziałkowski et al. (2012); and Stringer and Paavola (2013) consider as an essential challenge in protecting nature, while according to the concept of SD (from the $\mathrm{BR}$ ), and according to national legislation, the intersectoral cooperation is the basis of achieving the objectives of SD at the institutional level. It is necessary to harmonize more different sectors at the national level through discussions of experts. Ostrom (2005) points out the problem of ,intellectual poverty of institutions“ in the implementation of the objectives of sustainable development and Torkar and McGregor (2012) suggest that such problems can be solved with a transdisciplinary approach, within which there will be organized discussions of experts that will lead to understanding of the objectives of SD by all parties and creating shared values for the achievement of these objectives.

Governmental institutions in the future should work to create a communication strategy primarily for N2000 areas and for the population of these territories in accordance with the concept of SD (in line with transdisciplinary access). The role of such a document would be the greater harmonization of local and national objectives with international needs. The focus should be on developing the participation of local people in the management of protected areas which in the $\mathrm{RC}$ is characterized as being non-existent in protected areas. It is necessary to organize new management models of N2000 areas with a greater involvement of the public in their work („greater democratization " of public institutions) what Dietz et al. (2003) consider as a main challenge of SD.

\subsubsection{The challenge of the third pillar of the $A C$ according to the $B D$ and $H D$}

Hartley and Wood (2005) consider that proper access to justice is a basic challenge in protecting nature. The judiciary that did not have a long practice in disputes related to nature protection $(\mathrm{N} 4, \mathrm{~N} 5)$ significantly contributed to the unequal performance of the AC in the entire $\mathrm{RC}$ and is labeled by participants as ,not ready “ to deal with the problems of nature protection, which represents one of the future challenges which should be worked on. In addition, access to justice is rather expensive for the public and it requires additional training. Agenda 21 proposes symbolic access to justice in disputes of nature protection (UN, 1992). The Government would need to work more on the implementation of these principles of Agenda 21 in the future. Besides, it is necessary to invest more in educating the public about the possibilities of judicial proceedings in the nature protection sector at the national level so that the public could be more involved in nature protection through litigation, and thereby contribute to greater protection of nature.

\section{CONCLUSION}

The processes of Europeanization in the RC has led to the implementation of the objectives of the $\mathrm{BD}, \mathrm{HD}$ and the principles of the $\mathrm{AC}$ into the national legislation which are necessary for the establishment of MLG of N2000. The implementation of interna- 
tional obligations into national law and the process of establishing MLG of N2000 in turn led to the inclusion of new actors in nature protection, such as the EU and NGOs; the transformation of governmental institutions; strengthening of NGOs; and changing the relationships of governmental and non-governmental actors in the decision-making process within the national nature protection system.

The BD and HD have caused the transformation of governmental institutions and the strengthening of NGOs to the needs of gathering information. There was an increase in the number of employees, strengthening the capacity of governmental and NGOs assisted by EU funding. Also, new institutions were established for the management of N2000 areas and new NGOs in the field of nature protection. New relationships were also established at the national level in making decisions according to the implemented principles of the AC. Non-governmental actors became equal in decision-making alongside governmental actors at the national level. Such legal equality has contributed to the development of the public involvement in nature protection through NGOs. This led to altering public awareness and to the first major participation in the nature protection system in the RC.

After establishing MLG of N2000 public participation and equality in the decision-making process of governmental and non-governmental actors has become an integral part of the national system of nature protection. For further development of the nature protection system in the RC in accordance with the objectives of SD it is necessary to work on developing the principles of the AC towards achieving the objectives of the $\mathrm{BD}$ and $\mathrm{HD}$.

\section{REFERENCES}

Apostolopoulou, E., Drakou, E. G. and Pediaditi, K. (2012). Participation in the management of Greek Natura 2000 sites: Evidence from a cross-level analysis. Journal of Environmental Management, 113: 308-318.

Armitage, D. (2005). Adaptive capacity and community-based natural resource management. Environmental Management, 35(6): 703-715.

Arnberger, A., Eder, R., Allex, B., Sterl, P. and Burns, R. C. (2012). Relationships between national-park affinity and attitudes towards protected area management of visitors to the Gesaeuse National Park, Austria. Forest Policy and Economics, 19: 48-55.

Bache, I., Andreou, G., Atanasova, G. and Tomsic, D. (2011). Europeanization and multi-level governance in south-east Europe: the domestic impact of EU cohesion policy and pre-accession aid. Journal of European Public Policy, 18(1): 122-141.

Bache, I. and Tomsic, D. (2010). Europeanization and multi-level governance in Croatia. Southeast European and Black Sea Studies, 10(1): 97-110.

Baker, S. (2003). The Dynamics of European Union Biodiversity Policy: Interactive, Functional and Institutional Logics. Environmental Politics, 12(3): 23-41. 
Bennett, N. (2016). Using perceptions as evidence to improve conservation and environmental management. Conservation Biology, 30(3): 582-592.

Beunen, R. and de Vries, J. R. (2011). The governance of Natura 2000 sites: the importance of initial choices in the organisation of planning processes. Journal of Environmental Planning and Management, 54(8): 1041-1059.

Blenckner, T., Österblom, H., Larsson, P., Andersson, A. and Elmgren, R. (2015). Baltic Sea ecosystem-based management under climate change: Synthesis and future challenges. Ambio, 44(3): 507-515.

Bojicic-Dzelilovic, V. and Kostovicova, D. (2013). Europeanisation and conflict networks: private sector development in post-conflict Bosnia-Herzegovina. East European Politics, 29(1): 19-35.

Booth, A. and Halseth, G. (2011). Why the public thinks natural resources public participation processes fail: A case study of British Columbia communities. Land use policy, 28(4): 898-906.

Borgström, S., Bodin, Ö. and Sandström, A., Crona, B. (2015). Developing an analytical framework for assessing progress toward ecosystem-based management. Ambio, 44(3): 357-369.

Börzel, T. and Buzogány, A. (2010). Environmental organisations and the Europeanisation of public policy in Central and Eastern Europe: the case of biodiversity governance. Environmental Politics, 19(5): 708-735.

Brown, M. L. (2013). European Union Environmental Governance in Transition - Effective? Legitimate? Ecologically Rational? Journal of Information and Organizational Sciences, 4: 109-126.

Brulle, R. (2010). Politics and the Environment. In: Leicht, K. T. and Jenkins, J. C. (eds.), The Handbook of Politics: State and Civil Society in Global Perspective (pp. 385-406). New York: Springer Publishers.

Bulkeley, H. and Mol, P. J. A. (2003). Participation and Environmental Governance: Consensus, Ambivalence and Debate. Environmental Values, 12(2): 143-154.

Carlsson, L. and Berkes, F. (2005). Co-management: Concepts and methodological implications. Journal of Environmental Management, 75(1): 65-76.

Carmin, J., 2010. NGO capacity and environmental governance in Central and Eastern Europe. Acta Politica, 45(1): 183-202.

Cent, J., Grodzińska-Jurczak, M. and Pietrzyk-Kaszyńska, A. (2014). Emerging multilevel environmental governance - A case of public participation in Poland. Journal for Nature Conservation, 22(2): 93-102.

Cent, J., Mertens, C. and Niedziałkowski, K. (2013). Roles and impacts of non-governmental organizations in Natura 2000 implementation in Hungary and Poland. Environmental Conservation 40(2): 119-128.

Croatian Parliament. (2009). Strategija održivog razvitka Republike Hrvatske. Official Gazette of the Republic of Croatia 30/2009.

Croatian Parliament. (2010). Ustav Republike Hrvatske. Official Gazette of the Republic of Croatia 05/14. 
Croatian Parliament. (2013a). Zakon o zaštiti okoliša. Official Gazette of the Republic of Croatia 80/2013.

Croatian Parliament. (2013b). Zakon o zaštiti prirode. Official Gazette of the Republic of Croatia 80/2013.

Denti, D. (2014). The Europeanisation of candidate countries : the case for a shift to the concept of EU member-state building. Contemporary Southeastern Europe, 1(1): 9-32.

Dietz, T., Ostrom, E. and Stern, P. (2003). Struggle to Govern the Commons. Science, 302(5652): 1907-1912.

Dimitrakopoulos, P. G., Jones, N., Iosifides, T., Florokapi, I., Lasda, O., Paliouras, F. and Evangelinos, K. I. (2010). Local attitudes on protected areas: Evidence from three Natura 2000 wetland sites in Greece. Journal of Environmental Management, 91(9):1847-1854.

European Environment Agency (EEA). (2010). Assessing biodiversity in Europe - the 2010 report. Copenhagen: EEA.

European Economic Community (EEC). (1972). Council Directive (79/409/EEC) of 2 April 1979 on the conservation of wild birds. Brussels: European Commission.

European Economic Community (EEC). (1992). Council Directive (92/43/EEC) of 21 May 1992 on the conservation of natural habitats and of wild fauna and flora. Brussels: European Commission.

Fagan, A. (2005). Civil society in Bosnia ten years after Dayton. International Peacekeeping, 12(1): 406-419.

Fagan, A. (2006a). Neither „north“ nor „south“: The environment and civil society in post-conflict Bosnia-Herzegovina. Environmental Politics, 15(5): 787-802.

Fagan, A. (2006b). Transnational aid for civil society development in post-socialist Europe: Democratic consolidation or a new imperialism? Journal of Communist Studies and Transition Politics, 22(1): 115-134.

Fagan, A. (2008). Global-local linkage in the Western Balkans: The politics of environmental capacity building in Bosnia-Herzegovina. Political Studies, 56(3): 629-652.

Fagan, A. (2011). EU Conditionality and Governance in Bosnia \& Herzegovina: Environmental Regulation of the Trans-European Road Network. Europe Asia Studies, 63(10): 1889-1909.

Fagan, A. and Sircar, I. (2010a). Environmental politics in the Western Balkans: river basin management and non-governmental organisation (NGO) activity in Herzegovina. Environmental Politics, 19(5): 808-830.

Fagan, A. and Sircar, I. (2010b). Compliance without governance: the role of NGOs in environmental impact assessment processes in Bosnia-Herzegovina. Environmental Politics, 19(4): 599-616.

Fagan, A. and Sircar, I. (2012). Promoting democracy in the Western Balkans after the global economic crisis. London: LSEE - Research on South Eastern Europe.

Fernández, A. M., Font, N. and Koutalakis, C. (2010). Environmental governance in Southern Europe: the domestic filters of Europeanisation. Environmental Politics, 19(4): 557-577. 
Ferranti, F., Beunen, R. and Speranza, M. (2010). Natura 2000 Network: A Comparison of the Italian and Dutch Implementation Experiences. Journal of Environmental Policy \& Planning, 12(3): 293-314.

Geitzenauer, M., Hogl, K. and Weiss, G. (2016). Land Use Policy The implementation of Natura 2000 in Austria - A European policy in a federal system. Land use policy 52: $120-135$.

Gifford, R. and Nilsson, A. (2014). Personal and social factors that influence pro-environmental concern and behaviour: A review. International Journal of Psychology, 49(3): 141-157.

Giljum, S., Hak, T., Hinterberger, F. and Kovanda, J. (2005). Environmental governance in the European Union: strategies and instruments for absolute decoupling. International Journal of Sustainable Development, 8(1-2): 31-46.

Gioti Papadaki, O. (2012). European Environmental Policy and the Strategy „Europe 2020." Regional Science Inquiry Journal, 4(1): 151-158.

Government of the Republic of Croatia (2007). Uredba o proglašenju ekološke mreže. Official Gazette of the Republic of Croatia 109/2007.

Grodzinska-Jurczak, M. and Cent, J. (2011). Expansion of nature conservation areas: Problems with Natura 2000 implementation in Poland? Environmental Management, 47(1): 11-27.

Gruby, R. L. and Basurto, X. (2013). Multi-level governance for large marine commons: Politics and polycentricity in Palau's protected area network. Environmental Science \& Policy, 33: 260-272.

Hartley, N. and Wood, C. (2005). Public participation in environmental impact assessment - Implementing the Aarhus Convention. Environmental Impact Assessment Review, 25(4): 319-340.

Hiedanpaa, J. (2002). European-wide conservation versus local well-being: The reception of the Natura 2000 Reserve Network in Karvia, SW-Finland. Landscape and Urban Planning, 61(2-4) 113-123.

Holling, C. S. (1993). Gyroscope: Negotiation and Conflict. In: Lee, K. N. (ed.), Compass and Gyroscope: Integrating Science and Politics for the Environment (pp. 87-114). Washington: Island Press.

Hunka, A. and de Groot, W. T. (2011). Participative environmental management and social capital in Poland. Social Geography Discussions, 6(1): 39-50.

Imperial, M. (1999). Institutional Analysis and Ecosystem-Based Management: The Institutional Analysis and Development Framework. Environmental Management, 24(4): 449-465.

International Union for Conservation of Nature (IUCN). (1980). World Conservation Strategy - Living Resource Conservation for Sustainable Development. Geneva: IUCN.

Jones, N., Iosifides, T., Evangelinos, K. I., Florokapi, I. and Dimitrakopoulos, P. G. (2012). Investigating knowledge and perceptions of citizens of the National Park of Eastern Macedonia and Thrace, Greece. International Journal of Sustainable Development \& World Ecology, 19(1): 25-33. 
Jordan, A. (1998). The Politics of a Multi-level Environmental Governance System: European Union Environmental Policy at 25. CSERGE Working Paper No. 98-01. Norwich: University of East Anglia.

Jordan, A., Wurzel, R. and Zito, A. (2000). Innovating with „New“ Environmental Policy Instruments : Convergence or Divergence in the European Union. Annual Meetings of the American Political Science Association, August 31 - September 3. Washington: American Political Science Association.

Kapaciauskaite, I. (2011). Environmental governance in the Baltic Sea Region and the role of non-governmental actors. Procedia - Social and Behavioral Sciences, 14: 90100.

Kati, V., Hovardas, T., Dieterich, M., Ibisch, P. L., Mihok, B. and Selva, N. (2014). The challenge of implementing the European network of protected areas Natura 2000. Conservation Biology, 29(1): 260-270.

Kay, K. (2014). Europeanization through biodiversity conservation: Croatia's bid for EU accession and the Natura 2000 designation process. Geoforum, 54: 80-90.

Kluvánková-Oravská, T., Chobotová, V., Banaszak, I., Slavikova, L. and Trifunovova, S. (2009). From government to governance for biodiversity: The perspective of Central and Eastern European transition countries. Environmental Policy and Governance, 19(3): 186-196.

Kohler-Koch, B. and Rittberger, B. (2006). Review Article : The „Governance Turn“ in EU Studies. Journal of Common Market Studies, 44(1): 27-49

Krenova, Z. and Kindlmann, P. (2015). Natura 2000 - Solution for Eastern Europe or just a good start? The Sumava National Park as a test case. Biological Conservation, 186: $268-275$.

Lakićević, M. and Tatović, N. (2012). Primena Ekosistemskog Pristupa u Integralnom Upravljanju Prirodnim Resursima. Letopis naučnih radova, 36(1): 36-43.

Lockwood, M., Davidson, J., Curtis, A., Stratford, E. and Griffith, R. (2009). Multi-level Environmental Governance: lessons from Australian natural resource management. Australian Geographer, 40(2): 169-186.

Lockwood, M., Davidson, J., Curtis, A., Stratford, E. and Griffith, R. (2010). Governance Principles for Natural Resource Management. Society \& Natural Resources, 23(10): 986-1001.

Louette, G., Adriaens, D., Adriaens, P., Anselin, A., Devos, K., Sannen, K., Van Landuyt, W., Paelinckx, D. and Hoffmann, M. (2011). Bridging the gap between the Natura 2000 regional conservation status and local conservation objectives. Journal for Nature Conservation, 19(4): 224-235.

Lukšič, A. (1999). Rizična Tehnologija: Izziv Demokraciji. Ljubljana: Študentska organizacija Univerze v Ljubljani.

Lukšič, A. (2001). Rizične tehnologije kot izziv za premislek o odločevalskih formah. Teorija in Praksa, 38(3): 412-422.

Lukšič, A. (2002). Politološki premislek ob Aarhuški konvenciji. Teorija in Praksa, 39(3): 321-330. 
Lukšič, A. (2009). Konec demokracije? Teorija in Praksa, 46(5): 7-28.

Lukšič, A. (2010). Trajnosti razvoj, znanstveni diskurzi in nova politika. In: Lukšič, A. (ed.), Politološke Refleksije (pp. 423-435). Ljubljana: Center za kritično politologijo. McAnulla, S. (2005). Struktura i djelovanje. In: Marsh, D. and Stoker, G. (eds.), Teorije i Metode Političke Znanosti (pp. 279-286). Zagreb: Fakultet političkih znanosti.

Mertens, C. (2013). Playing at multiple levels in biodiversity governance: The case of Hungarian ENGOs in Natura 2000. Society and Economy, 35(2): 187-208.

Neumann, R. R. (2005). Making Political Ecology. In: Neumann, R. R. (ed.), Making Political Ecology (pp. 118-153). New York: Oxford University Press.

Newig, J. and Fritsch, O. (2009). Environmental governance: Participatory, multi-level - And effective? Environmental Policy and Governance, 19(3): 197-214.

Niedziałkowski, K., Paavola, J. and Jedrzejewska, B. (2012). Participation and protected areas governance: The impact of changing influence of local authorities on the conservation of the Białowieża primeval forest, Poland. Ecology and Society, 17(1): 2. DOI: $10.5751 /$ ES-04461-170102

Niedziałkowski, K., Pietrzyk-Kaszyńska, A., Pietruczuk, M. and Grodzińska-jurczak, M. (2015). Assessing participatory and multi-level characteristics of biodiversity and landscape protection legislation : the case of Poland. Journal of Environmental Planning and Management, 59(10): 1891-1911.

Nilsson, A. K. and Bohman, B. (2015). Legal prerequisites for ecosystem-based management in the Baltic Sea area: The example of eutrophication. Ambio, 44(3): 370380.

Oberthür, S., Buck, M., Müller, S., Pfahl, S., Tarasofsky, R. G. and Werksman, J. (2003). Participation of Non-Governmental Organisations in International Environmental Governance - Legal Basis and Practical Experience. Berlin: Ecologic.

Ostrom, E. (1990). Governing the Commons: The evolution of institutions for collective action. Cambridge: Cambridge University Press.

Ostrom, E. (2005). Understanding Institutional Diversity. New Jersey: Princeton University Press.

Pietrzyk-Kaszyńska, A., Cent, J., Grodzińska-Jurczak, M. and Szymańska, M. (2012). Factors influencing perception of protected areas - The case of Natura 2000 in Polish Carpathian communities. Journal for Nature Conservation, 20(5): 284-292.

Plitvice Lakes National Park (2007). Nacionalni park Plitvička jezera - plan upravljanja., Zagreb: Republički zavod za zaštitu prirode Republike Hrvatske.

Plitvice Lakes National Park (2014). Statut javne ustanove Nacionalni park Plitvička jezera. Plitvice Lakes: Nacionalni park Plitvička jezera.

Reisigl, M. and Wodak, R., 2016. The Discourse-Historical Approach (DHA). In: Wodak, R. and Meyer, M. (eds.), Methods of Critical Discourse Studies (pp. 24-58). London: Sage Publications Ltd.

Robinson, O. C. (2014). Qualitative Research in Psychology Sampling in InterviewBased Qualitative Research: A Theoretical and Practical Guide. Qualitative Research in Psychology, 11(1): 25-41. 
Romano, B. and Zullo, F. (2015). Protected Areas, Natura 2000 Sites and Landscape: Divergent Policies on Converging Values. In: Gambino, R. and Peano, A. (eds.), Nature Policies and Landscape Policies: Towards an Alliance (pp. 127-135). Cham: Springer International Publishing.

Rosa, H. D. and Da Silva, J. M. (2005). From environmental ethics to nature conservation policy: Natura 2000 and the burden of proof. Journal of Agricultural and Environmental Ethics, 18(2): 107-130.

Schusler, T. M., Decker, D. J. and Pfeffer, M. J. (2003). Social Learning for Collaborative Natural Resource Management. Society \& Natural Resources, 16(4) 309-326.

Slocombe, D. S. (1998). Defining Goals and Criteria for Ecosystem-Based Management. Environmental Management, 22(4): 483-493.

State Institute for Nature protection. (2006). Nacionalna ekološka mreža - važna područja za ptice. URL http://www.dzzp.hr/publikacije/brosure-i-bilteni/nacionalna-ekoloska-mreza-vazna-podrucja-za-ptice-u-hrvatskoj-400.html (January, 2017).

State Institute for Nature protection. (2009). PHARE 2005 „Institucionalno jačanje i provedba ekološke mreže NATURA 2000 u Hrvatskoj“. URL: http://www.dzzp.hr/ projekti-iz-eu-fondova/phare/phare-2005-institucionalno-jacanje-i-provedba-ekoloske-mreze-natura-2000-u-hrvatskoj-2008-2009-763.html (January, 2017).

State Institute for Nature protection. (2011). IPA 2007 „Identifikacija i uspostavljanje morskog djela ekološke mreže NATURA 2000 u Hrvatskoj“. URL: http://www. dzzp.hr/projekti-iz-eu-fondova/ipa/ipa-2007-\%E2\%80\%9Eidentifikacija-i-uspostavljanje-morskog-dijela-mreze-natura-2000-u-hrvatskoj\%E2\%80\%9C-803. html (January, 2017).

State Institute for Nature protection. (2013). IPA 2009 „NATURA 2000: Uspostava upravljanja i monitoringa“. URL: http://www.dzzp.hr/projekti-iz-eu-fondova/ ipa/ipa-2009-\%E2\%80\%9Enatura-2000-uspostava-upravljanja-i-monitoringamanmon\%E2\%80\%9C-804.html (January, 2017).

Stringer, L. C. and Paavola, J. (2013). Participation in environmental conservation and protected area management in Romania: A review of three case studies. Environmental Conservation, 40(2): 138-146.

Stubbs, P. (2005). Stretching Concepts Too Far ? Multi-Level Governance, Policy Transfer and the Politics of Scale. Southeast European Politics, 6(2): 66-87.

Torkar, G. (2014). Learning experiences that produce environmentally active and informed minds. NJAS - Wageningen Journal of Life Sciences, 69: 49-55.

Torkar, G. and McGregor, S. L. T. (2012). Reframing the conception of nature conservation management by transdisciplinary methodology: From stakeholders to stakesharers. Journal for Nature Conservation, 20(2): 65-71.

United Nations (UN). (1992). Agenda 21. Rio de Janeiro: United Nations.

Weber, N. and Christophersen, T. (2002). The influence of non-governmental organisations on the creation of Natura 2000 during the European Policy process. Forest Policy and Economics, 4(1): 1-12. 
Winkel, G., Blondet, M., Borrass, L., Frei, T., Geitzenauer, M., Gruppe, A., Jump, A., de Koning, J., Sotirov, M., Weiss, G., Winter, S. and Turnhout, E. (2015). The implementation of Natura 2000 in forests: A trans- and interdisciplinary assessment of challenges and choices. Environmental Science \& Policy, 52: 23-32.

Winter, S., Borrass, L., Geitzenauer, M., Blondet, M., Breibeck, R., Weiss, G. and Winkel, G. (2014). The impact of Natura 2000 on forest management: a socioecological analysis in the continental region of the European Union. Biodiversity and Conservation, 23(14): 3451-3482.

Wurzel, R. K. W. (2008). European Union Environmental Policy and Natura 2000: From Adoption to Revision. In: Keulartz, J. and Leistra, G. (eds.), Legitimacy in European Nature Conservation Policy: Case Studies in Multilevel Governance (pp. 259-282). Hull: University of Hull.

Zito, A. R. (2005). The European Union as an environmental leader in a global environment. Globalizations 2(3): 363-375. 


\title{
UČINCI EUROPEIZACIJE SUSTAVA ZAŠTITE PRIRODE U HRVATSKOJ: PRIMJER USPOSTAVE VIŠESTUPANJSKOG SUSTAVA ZA UPRAVLJANJE ZAŠTIĆENIM PODRUČJIMA „NATURA 2000“
}

\author{
Aleksandar Šobot i Andrej Lukšič
}

\begin{abstract}
Sažetak
Proces europeizacije Jugoistočne Europe u Hrvatskoj ogledao se kroz provedbu pristupnih pregovora te, u konačnici, u pristupanju Hrvatske Europskoj uniji. Službeni proces pristupanja Hrvatske Europskoj uniji započeo je 2003. i trajao do 2012. godine, odnosno 2013. godine kada se Hrvatska i službeno pridružila Europskoj uniji. U radu se istražuje učinak europeizacije na sustav zaštite prirode u Hrvatskoj u ovom pristupnom razdoblju tijekom kojeg je uspostavljen višestupanjski sustav za upravljanja zaštićenim područjima „Natura 2000“.

U radu donosimo analizu uspostave višestupanjskog sustava za upravljanje zaštićenim područjima koristeći studiju slučaja u tri faze, po uzoru na morfogenetski model. U prvoj fazi istražujemo primjenu Nature 2000 u Hrvatskoj te nekoliko izmjena nacionalne legislative iz područja zaštite prirode. U drugoj fazi objašnjavamo ulogu ključnih aktera u uspostavi višestupanjskog sustava "Natura 2000“. U trećoj fazi opisujemo čimbenike koji su doprinijeli uspostavi Nature 2000 kao sustava zaštite prirode u Hrvatskoj te ukazujemo na izazove koji pred njom stoje u budućnosti. Zaključujemo ukazujući na važne promjene koje su nastale kao posljedica primjene europske ekološke mreže "Natura 2000" u nacionalnom sustavu zaštite prirode u Hrvatskoj, poput preobrazbe vladinih institucija i ravnopravnijeg uključenja nevladinih organizacija u sustav donošenja odluka.
\end{abstract}

Ključne riječi: europeizacija, Jugoistočna Europa, Hrvatska, pristupanje Europskoj uniji, sustav zaštite prirode, Natura 2000

\section{AUSWIRKUNGEN DER EUROPÄISIERUNG DES NATURSCHUTZSYSTEMS IN KROATIEN: EIN BEISPIEL DER ERRICHTUNG DES MEHRSTUFIGEN VERWALTUNGSSYSTEMS FÜR NATURSCHUTZGEBIETE „NATURA 2000“}

\author{
Aleksandar Šobot und Andrej Lukšič
}

\section{Zusammenfassung}

Der Europäisierungsprozess des Südosteuropas in Kroatien spiegelte sich bei den Beitrittsverhandlungen und schließlich beim EU-Beitritt Kroatiens wider. Der offizielle Beitrittsprozess Kroatiens begann im Jahr 2003 und dauerte bis 2012, bzw. 2013, als Kroatien offiziell der EU beigetreten ist. In der Arbeit werden die Auswirkungen der Europäisierung auf das Naturschutzsystem in Kroatien erforscht, die während der Beitrittsperiode zustande kamen, als das mehrstufige Verwaltungssystem für Naturschutzgebiete „Natura 2000“ errichtet wurde. In der Arbeit analysieren wir die Errichtung des mehrstufigen Verwaltungssystems für Naturschutzgebiete, indem wir uns der Fallstudie in drei Phasen bedienen, nach dem Vorbild des morphogenetischen Modells. In der ersten Phase erforschen wir die Anwendung von Natura 2000 in Kroatien und einige Änderungen der nationalen Gesetzgebung im Naturschutzbereich. In der zweiten Phase erklären wir die Rolle von Schlüsselakteuren bei der Errichtung des mehrstufigen Systems "Natura 2000“. In der dritten Phase beschreiben wir die Faktoren, die der Errichtung von Natura 2000 in Kroatien beigetragen haben und weisen auf zukünftige Herausforderungen hin. Zum Schlußweisen wir auf wichtige Änderungen hin, die als Folge der Anwendung des europäischen ökologischen Netzes "Natura 2000“ im nationalen Naturschutzsystem Kroatiens entstanden sind, wie z.B. die Umwandlung von Regierungsinstitutionen und ein im höheren Maße gleichberechtigter Einschluß von Nichtregierungsorganisation ins System der Beschlussfassung.

Schlüsselwörter: Europäisierung, Südosteuropa, Kroatien, EU-Beitritt, Naturschutzsystem, Natura 2000 